$\begin{array}{ccc}\text { Tersedia online di: http://ejournal-balitbang.kkp.go.id/index.php/jppi } & \text { JURNAL } \\ \text { e-mail:jppi.puslitbangkan@ gmail.com } & \text { PENELITIAN } \\ \text { PERIKANAN } & \text { INDONESIA } \\ \text { JURNAL PENELITIANPERIKANANINDONESIA } & \text { Volume 26 Nomor 3 September 2020 } \\ \text { p-ISSN: 0853-5884 } \\ \text { e-ISSN: 2502-6542 }\end{array}$

\title{
KARAKTERISTIK PERIKANAN TERI (ENGRAULIDAE) DI PANTAI UTARA JAWA-MADURA
}

\section{CARACTERISTIC OF ANCHOVY FISHERIES (ENGRAULIDAE) IN THE NORTH COAST OF JAVA-MADURA}

\author{
Achmad Zamroni*1, Heri Widiyastuti ${ }^{1}$ dan Suwarso ${ }^{1}$ \\ ${ }^{1}$ Balai Riset Perikanan Laut, Komp. Raiser JI Raya Bogor Km. 47, Cibinong, Bogor-Jawa Barat, Indonesia \\ Teregistrasi I tanggal: 09 September 2019; Diterima setelah perbaikan tanggal: 22 Desember 2020; \\ Disetujui terbit tanggal: 29 Desember 2020
}

\begin{abstract}
ABSTRAK
Perikanan teri berkembang sangat pesat khususnya di perairan utara Jawa Madura pada tahun terakhir ini. Kajian tentang karakteristik perikanan teri (Engraulidae) di sepanjang pantai utara Jawa-Madura dilaksanakan pada tahun 2017-2018, meliputi sebaran usaha perikanan, tipe armada-alat penangkapan ikan, aspek operasional penangkapan, hasil tangkapan-kelimpahan dan musim penangkapan ikan teri. Pengumpulan data pendaratan ikan teri dilakukan melalui survey di 11 lokasi pendaratan ikan. Hasil penelitian menunjukkan terdapat 12 lokasi tempat pendaratan utama ikan teri di sepanjang pantai utara (pantura) Jawa dan Madura. Dua jenis alat dominan digunakan untuk penangkapan teri adalah pukat cincin dan payang; perikanan bersifat skala kecil, melakukan trip harian, dengan armada kapal penangkap berukuran dibawah 20 GT. Jaring umumnya menggunakan waring dengan mata jaring kecil ( $3 / 8$ inch) di bagian kantong. Daerah penangkapan di perairan pantai yang dangkal, dekat dengan basis perikanan. Musim penangkapan ikan teri bervariasi, di wilayah bagian barat (Pulolampes, Larangan, Morodemak) berlangsung sekitar musim timur/tenggara (Mei Juli), sedangkan di wilayah bagian timur berlangsung pada awal musim timur dan berjalan cukup lama hingga bulan November (musim peralihan 2). Hasil tangkapan per unit upaya (CPUE, sebagai indek kelimpahan) diduga makin ke arah timur semakin rendah namun disertai musim penangkapan ikan lebih lama.
\end{abstract}

Kata Kunci: Karakteristik; perikanan teri; Laut Jawa; Selat Madura

\begin{abstract}
Anchovy fishery has grown rapidly, especially in the northern waters of Java-Madura in the last year. The study on the characteristics of the anchovy fishery (Engraulidae) along the northern coast of Java-Madura was carried out in 2017-2018, covering the distribution of fisheries effort, types of fishing gear, operational aspects of fishing, catch-abundance and fishing season. The collection of anchovy landing data was carried out through a survey at 11 fish landing sites. The results showed that there were 12 main anchovy landing sites along the north coast (pantura) of Java and Madura. Two types of dominant fishing gear used for anchovies are purse seine and payang; Fisheries are small-scale, undertaking daily trips, with a fleet of fishing vessels under 20 GT. The nets generally use "waring" with small mesh (3/8 inch) in the codend. Fishing area in shallow coastal waters, close to the fishing base. The fishing season for anchovy varies, in the western region (Pulolampes, Larangan, Morodemak) it takes place around the east / southeast season (May-July), while in the eastern region it takes place at the beginning of the eastern season and lasts quite a long time until November (transition season 2). The catch per unit effort (CPUE, as an abundance index) is thought to be getting lower eastward but accompanied by a longer fishing season.
\end{abstract}

Keywords: Characteristics; anchovy fisheries; Java Sea; Madura Strait

Korespondensi penulis:

ironzammiden@gmail.com

DOI: http://dx.doi.org/10.15578/jppi.26.3.2020.135-146 


\section{PENDAHULUAN}

Ikan teri (Fam. Engraulidae) termasuk ke dalam kelompok ikan pelagis kecil yang berukuran kecil, biasanya hidup bergerombol di perairan pantai dan estuarin (Hutomo et al., 1987). Sumberdaya ikan teri ditemukan tersebar luas hampir mencakup seluruh perairan Indonesia dan sampai saat ini ditemukan 9 jenis ikan teri di perairan Indonesia (Nontji, 2005). Ikan teri merupakan komoditi penting dan bersifat strategis sebagai sumber protein, harga lebih terjangkau, memiliki nilai eksport serta dapat digunakan sebagai ikan umpan hidup (puri merah, Encrasicholina heteroloba) bagi perikanan huhate (pole and line) khususnya untuk menangkap tuna dan cakalang di wilayah Indonesia bagian timur.

Berdasarkan statistik perikanan Provinsi. Jawa Tengah tahun 2015 produksi ikan teri tercatat sebesar 23.563 ton dengan rincian sebanyak $29 \%$ dari Brebes, $26 \%$ dari Pemalang, $19 \%$ dari Tegal, $11 \%$ dari Kendal, $6 \%$ dari Demak; sisanya dari Jepara, Pekalongan, Pati, Rembang, Semarang. Selanjutnya menurut Statistik Perikanan Provinsi. Jawa Timur melaporkan produksi ikan teri dan teri nasi masing-masing sekitar 13.617 ton dan 7.124 ton, dimana konstibusi paling banyak berasal dari Kabupaten Lamongan (3.119 ton); kemudian Kabupaten Pamekasan tercatat 1.597 ton ikan teri dan 2.372 ton ikan teri nasi; Kabupaten Gresik mencatat produksi teri sekitar 1.237 ton.

Diversifikasi alat tangkap teri belakangan ini telah makin berkembang. Pada awalnya nelayan menangkap teri menggunakan alat tangkap bagan (khususnya di Jepara, Semarang, Demak), payang gemplo/teri/waring (di Tegal, Pemalang, Gresik,
Pamekasan) dan jaring arad (di Tegal, Pemalang, Semarang)., Pada beberapa tahun terakhir ini terjadi inovasi alat tangkap pukat cincin 'waring' terutama oleh nelayan Brebes, Tegal dan Demak untuk tujuan peningkatan hasil tangkapan ikan teri namun inovasi ini telah memunculkan konflik horisontal secara nasional walaupun aktivitas pemanfaatan tetap berlangsung.

Makalah ini menyampaikan tentang sebaran daerah penangkapan, armada dan alat penangkapan ikan, operasional penangkapan, hasil tangkapan dan karakteristik biologi (jenis dan ukuran) ikan teri di beberapa lokasi pendaratan ikan di pantura JawaMadura pada periode 2017-2018. Hasil penelitian ini diharapkan dapat menjadi dasar kajian stok sumberdaya ikan teri sehingga dapat menjadi landasan bagi pengelolaan sumberdaya secara berkelanjutan dan lestari.

\section{BAHAN DAN METODE Pengumpulan Data}

Data yang dikumpulkan meliputi data total hasil tangkapan ikan teri yang didaratkan di setiap tempat pendaratan ikan terpilih secara bulanan maupun tahunan, karakteristik kapal dan alat penangkapan ikan serta upaya penangkapan, data harian hasil tangkapan per kapal di beberapa lokasi, operasional penangkapan dan daerah penangkapan, komposisi jenisserta data biologi (struktur ukuran ikan). Informasi tempat pendaratan ikan diperoleh melalui survey di tempat pendaratan ikan dengan mengumpulkan datadata statistik pendaratan (hasil tangkapan dan jumlah upaya). Gambar 1 menunjukkan beberapa lokasi tempat pendaratan ikan teri yang diteliti di perairan utara Jawa dan Selat Madura.

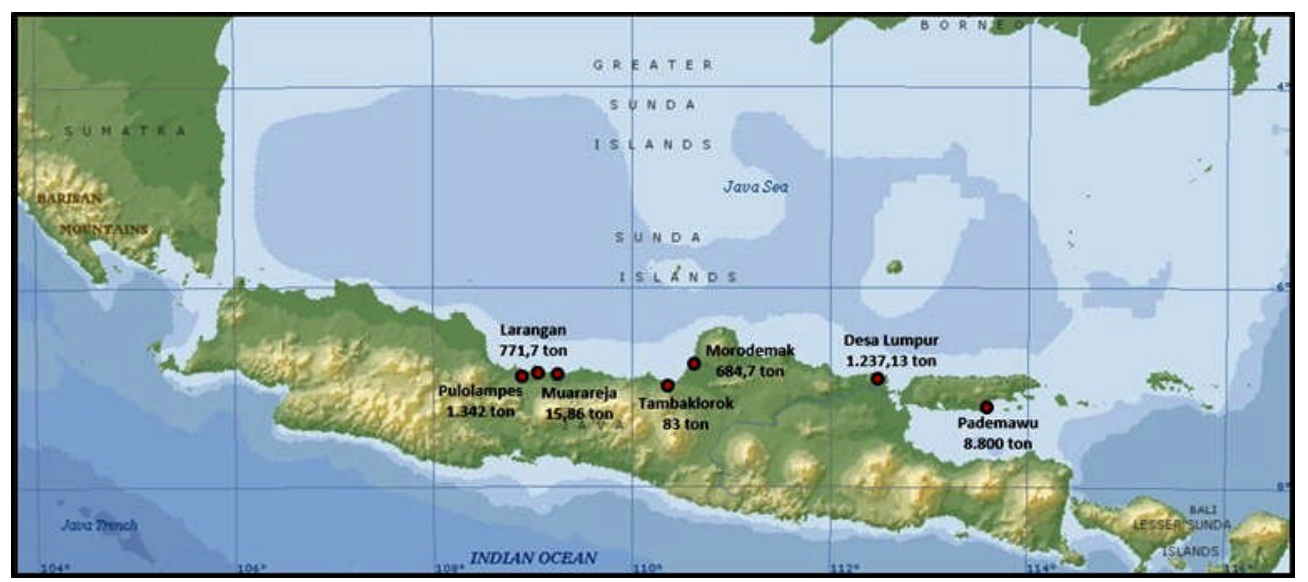

Gambar 1. Lokasi pendaratan ikan sebagai tempat pengumpulan data perikanan teri.

Figure 1. Fish landing places for anchovy fisheries data collection. 
Pencatatan hasil tangkapan per kapal per jenis ikan oleh petugas TPI dilaksanakan hanya terhadap alat tangkap utama (pukat cincin waring dan payang) di lokasi Pulolampes, Larangan dan Morodemak pelaksanaan pengumpulan data per kapal dilakukan dengan bantuan enumerator. Pengumpulan data karakteristik armada dan alat penangkapan ikan serta operasional penangkapan (daerah penangkapan, aktivitas penangkapan) dilaksanakan melalui observasi di lapangan dan melakukan wawancara dengan nakhoda kapal atau nelayan; sedangkan data biologi dikumpulkan melalui pengambilan contoh ikan terhadap jenis ikan teri dominan tertangkap (teri seret putih) yang dilakukan secara acak sebanyak dua kali sampling per minggu dengan jumlah sampel ikan 100 ekor untuk setiap kali sampling di TPI Morodemak.

\section{Analisis Data}

Analisis kelimpahan ikan teri yang diindikasikan oleh besaran nilai tangkapan per satuan upaya (catch per unit effort/CPUE) mengacu pada Schaefer (1957) yang dikemukakan oleh Gulland (1983) dengan rumus:

$C P U E_{\mathrm{t}}=$ Catch $_{\mathrm{t}}$ Effort $_{\mathrm{t}}$

Dimana:

CPUE $_{\mathrm{t}}=$ hasil tangkapan per satuan upaya penangkapan pada tahun ke- $\mathrm{t}(\mathrm{kg} / \mathrm{trip})$;

Catch $_{\mathrm{t}}=$ hasil tangkapan pada tahun $\mathrm{ke}-\mathrm{t}(\mathrm{kg})$;

Effort $_{\mathrm{t}}=$ upaya penangkapan pada tahun ke- $\mathrm{t}$ (trip).

Analisis hubungan panjang berat ikan mengacu pada Paully (1984) dengan rumus:

$\mathrm{W}=\mathrm{a} \cdot \mathrm{L}^{\mathrm{b}}$

Persamaan tersebut diubah ke dalam persamaan linier, menjadi:

$\ln W=\ln a+b \ln L$

Dimana:

$\mathrm{W}=$ berat ikan (gram);

$\mathrm{L} \quad=$ panjang ikan $(\mathrm{cm})$;

In $\mathrm{a}=$ intercept

$\mathrm{b}=$ slope

Berdasarkan Effendie (2002), pola pertumbuhan dapat diketahui dari nilai $b$, dengan kretaria seperti berikut:

jika $b=3$ : Isometrik, berarti pertambahan panjangnya sama dengan pertambahan berat. jika $b \neq 3$ : Allometrik. untuk $b>3$ alometrik positif, dan jika $b<3$ allometrik negatif.

Uji t dilakukan pada nilai b untuk mengetahui sifat pertumbuhan suatu ikan dirumuskan sebagai berikut (Sokal \& Rohlf, 1987):

$t_{s}=\frac{b-3}{S_{b}}$

Dimana:

$\mathrm{t}_{\mathrm{s}}=$ hasil $\mathrm{t}$ hitung;

$\mathrm{b}=$ slope

$S_{b}=$ standard error slope $(b)$

Panjang pertama kali tertangkap (length at first capture, $\mathrm{L}_{\mathrm{c}}$ ) diperoleh dari metode Beverton \& Holt dalam Sparre \& Venema (1998):

$$
S L=\frac{1}{1+\exp (a-b L)}
$$

Dimana nilai dari a (intercept) dan b (slope) diperoleh dari persamaan regresi linear sebagai berikut:

$$
\operatorname{Ln}\left(\frac{1}{S L_{C}}-1\right)=a-b L
$$

Dimana:

$S L=$ estimasi nilai panjang;

$\mathrm{L} \quad=$ ilai tengah panjang $(\mathrm{cm})$;

$S L_{c}=$ frekuensi panjang relatif kumulatif. Nilai $L_{c}$ dapat diperoleh dari persamaan:

$L c=-a / b$

Koefisien pertumbuhan $(\mathrm{K})$ dan panjang maksimum/panjang asimptotik $\left(\mathrm{L}_{\infty}\right)$ ikan diperoleh berdasarkan Von Bertanlanffy Growth Function (VBGF). Parameter pertumbuhan tersebut didapatkan dengan menggunakan perangkat lunak R-Program versi 3.6.1 dengan paket TropFishR.

Laju kematian total ( $Z$ ) diperoleh dengan menggunakan analisis linearized length-converted catch curve (Sparre \& Venema, 1998). Selanjutnya laju kematian alami dapat diduga dengan menggunakan (Pauly, 1980):

$\log M=-0.0066-0.279 \log L_{\infty}+0.6543 \log K+$ $0.4634 \log \mathrm{T}$.

Dimana:

$M=$ laju kematian/mortalitas alami

$\mathrm{T}=$ rata-rata suhu air laut $\left({ }^{\circ} \mathrm{C}\right)$ 
Laju kematian akibat penangkapan (F) dapat diduga dengan menggunakan hubungan (Ricker, 1975 in Sparre \& Venema, 1998):

$Z=F+M$

Laju pemanfaatan/eksploitasi (E) ditentukan dengan membandingkan laju kematian akibat penangkapan $(F)$ dengan laju kematian total $(Z)$ dengan mengacu pada rumus Pauly (1984):

$$
E=\frac{F}{F+M}=F / M
$$

\section{HASIL DAN BAHASAN \\ Hasil}

\section{Keragaan Perikanan Teri di Perairan Utara Jawa}

Lokasi pendaratan hasil tangkapan ikan teri teridentifikasi sebanyak 12 lokasi di sepanjang pantai utara Jawa dan selat Madura yang terdiri dari 9 kabupaten/kota (Tabel 1). Tempat pendaratan ikan yang berlokasi di Jawa Tengah antara lain Pulolampes (Brebes), Tegalsari, Muarareja, Pengaradan (Tanjung), Krahan, Larangan, Asemdoyong, Tambaklorok, Jepara dan Morodemak; sedang yang berada di Jawa Timur berlokasi di Gresik dan Pamekasan (Madura) (Gambar 1). Jenis alat penangkapan ikan yang digunakan beragam seperti alat tangkap tipe pukat cincin waring, payang 'gemplo' atau payang 'jabur', bagan dan arad (pukat). Jaring yang digunakan pada masing-masing alat tangkap tersebut adalah jaring waring. Tipe usaha perikanan umumnya berskala kecil (tradisional) dengan perahu berukuran kecil (<30 GT). Karakteristik perikanan teri di Pantura Jawa dan Selat Madura dapat dilihat pada Tabel 1.

Tabel 1. Lokasi pendaratan ikan, alat tangkap dan jenis dominan pada perikanan teri (Engraulidae) di Pantura Jawa dan Selat Madura, 2018

Table 1. The fish landing site, fishing gear and dominant species on the Anchovy (Engraulidae) fisheries in Java's coast and Madura Strait, 2018

\begin{tabular}{|c|c|c|c|c|}
\hline LOKASI/ TPI & KAB/KOTA & ALAT TANGKAP & $\begin{array}{c}\text { JUMLAH } \\
\text { ARMADA (Unit) }\end{array}$ & $\begin{array}{c}\text { TARGET } \\
\text { SPECIES \& } \\
\text { Produksi } \\
\text { (Ton/tahun) }\end{array}$ \\
\hline Pulolampes & Brebes & PS waring (puring) & 140 & Teri (1342) \\
\hline Tegalsari & Tegal & $\begin{array}{l}\text { Payang gemplo } \\
\text { Arad }\end{array}$ & NA & \\
\hline Muarareja & Tegal & $\begin{array}{l}\text { Payang gemplo } \\
\text { Arad } \\
\text { Bundes/krikit }\end{array}$ & $\begin{array}{c}- \\
250 \\
25\end{array}$ & \\
\hline Pengaradan & Tegal & PS waring & & \\
\hline Larangan & Tegal & $\begin{array}{l}\text { PS waring } \\
\text { Payang gemplo } \\
\text { Payang teri }\end{array}$ & $\begin{array}{c}55 \\
75 \\
133\end{array}$ & $\begin{array}{l}\text { Teri-Teri nasi } \\
(772)\end{array}$ \\
\hline $\begin{array}{l}\text { Asemdoyong } \\
\text { Batang-Kendal }\end{array}$ & Pemalang & Payang gemplo & NA & Teri (1678) \\
\hline Tambaklorok & Semarang & $\begin{array}{l}\text { Bagan } \\
\text { Dogol }\end{array}$ & $\begin{array}{l}2 \\
5\end{array}$ & Teri (83) \\
\hline Jepara & Jepara & Bagan & NA & \\
\hline Morodemak & Demak & $\begin{array}{l}\text { PS waring (Bolga) } \\
\text { Bagan tancap }\end{array}$ & $\begin{array}{c}104 / 250 \\
-\end{array}$ & Teri (685) \\
\hline Ds. Lumpur & Gresik & $\begin{array}{l}\text { Payang teri } \\
\text { (jaring goyeng) }\end{array}$ & 1284 & Teri (1237) \\
\hline Pademawu & Pamekasan & $\begin{array}{l}\text { Payang waring } \\
\text { Purse Seine }\end{array}$ & $\begin{array}{c}284 \\
47\end{array}$ & $\begin{array}{l}\text { Teri (8800) } \\
\text { Kembung }\end{array}$ \\
\hline
\end{tabular}




\section{Sebaran Daerah Penangkapan Ikan Teri di Perairan Utara Jawa dan Selat Madura}

Berdasarkan observasi di lapangan daerah penangkapan (fishing ground) pukat cincin (purse seine) waring Pulolampes (Brebes) berada di pantai utara Jawa tepatnya antara Tegal hingga Cirebon yang berjarak 3-12 mil dari pantai (jalur 1 dan jalur 2 penangkapan) atau 3 jam perjalanan dengan kedalaman perairan $1-50 \mathrm{~m}$. Di sekitar Larangan (kapal purse seinewaring berukuran $<10 \mathrm{GT}$ dan kapal payang gemplo berukuran 3-4 GT) daerah penangkapan teri tersebar di pantai utara Tegal diperkirakan sekitar 2-3 mil dari pantai atau perjalanan 2-3 jam; teri hasil tangkapan berupa jenis 'teri glagah' (nama lokal), sedang payang gemplo banyak menangkap jenis "teri nasi". Daerah penangkapan teri di sekitar Semarang (mengoperasikan jaring dogol dan arad) dan Jepara (mengoperasikan bagan perahu) teridentifikasi menyebar di perairan pantai sekitar
Semarang sampai Jepara dengan kedalaman kurang dari 10 depa (15 meter) (Gambar 2).

Perikanan jaring bolga di Morodemak melakukan aktivitas penangkapan secara harian (one day fishing). Berdasarkan data yang dikumpulkan enumerator tahun 2017-2018 di TPI Morodemak diperoleh informasi daerah penangkapan jaring bolga berada sekitar pantai Morodemak dengan kedalama antara 1-50 m. Lokasi penangkapan ini selalu sama selama 2 tahun pendataan. Di sekitar Kabupaten Gresik daerah penangkapan 'jaring goyeng' (modifikasi dari payang) untuk menangkap teri tersebar di pantai Gresik bagian barat sampai perbatasan Lamongan, di bagian timur mencapai jembatan Suramadu. Aktivitas penangkapan nelayan Pamekasan (payang untuk teri dan teri nasi) bersifat harian sehingga daerah penangkapan tidak terlalu jauh dari basis pendaratan (Pamekasan) dan masih di sekitar Selat Madura. Umumnya di perairan Sampang hingga ke timur sampai ke peairan sekitar Sumenep (Gambar 2).

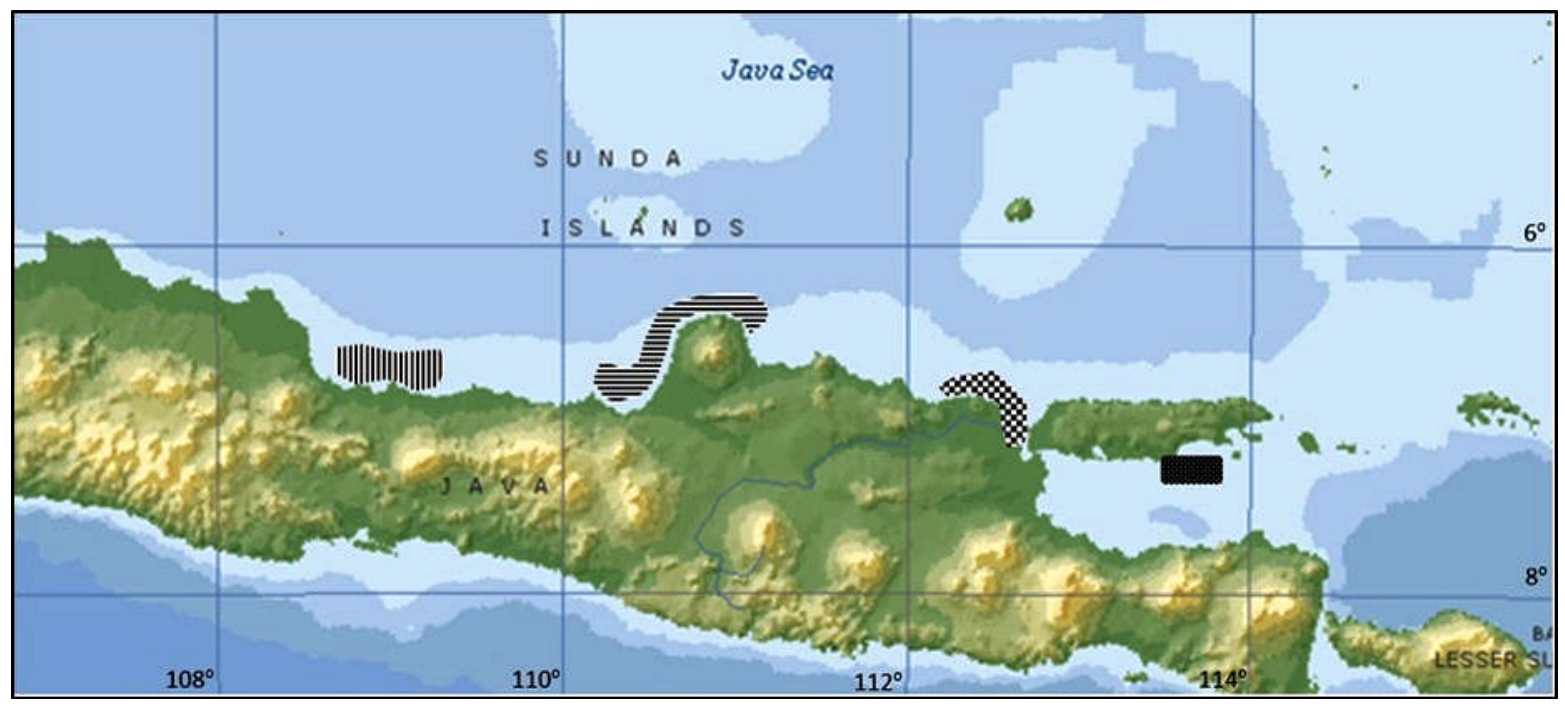

Gambar 2. Daerah penangkapan ikan teri di pantai utara Jawa dan Selat Madura.

Figure 2. Fishing ground of anchovy in north coast of Java and Madura Strait.

\section{Hasil Tangkapan dan Musim Penangkapan Ikan Teri}

Komposisi jenis ikan teri yang tertangkap di Utara Jawa didominasi oleh ikan teri 'gelagah' (Stolephorus commersonnii) dibandingkan dengan ikan teri nasi (Stolephorus spp.). Pendaratan di TPI Pulolampes, Brebes lebih dari $90 \%$ hasil tangkapan berupa ikan teri gelagah, ikan teri nasi tidak tertangkap. Hal yang sama juga terjadi di TPI Morodemak, Demak, ikan teri yang tertangkap adalah ikan teri gelagah, atau di Demak disebut juga teri seret putih. Ikan teri nasi tertangkap di TPI Larangan, Tegal dan Pademawu, Pamekasan, akan tetapi prosentase hasil tangkapan masih lebih rendah dibandingkan dengan teri gelagah.
Ikan teri nasi yang didaratkan di TPI Larangan, Tegal sekitar $8 \%$ dari total hasil tangkapan, sedangkan ikan teri gelagah sekitar $62 \%$.

Berdasarkan catatan harian di TPI Pulolampes, Brebes pada tahun 2017, rata-rata total hasil tangkapan teri per bulan sekitar 84 ton dengan variasi bulanan antara 23-227 ton/bulan dengan jumlah trip penangkapan antara 96-550 trip harian (one-day fishing). Total hasil tangkapan ikan teri yang didaratkan di TPI Larangan, Tegal pada tahun 2017 dan 2018 tercatat sebanyak 854 ton dan 797 ton. Kisaran hasil tangkapan ikan teri di TPI Morodemak, Demak selama 2017 dan 2018 menunjukkan kisaran antara $<100$ kg per kapal sampai $>1.000 \mathrm{~kg}$ per kapal. Tahun 2017 
hasil tangkapan $<100 \mathrm{~kg}$ per kapal mempunyai prosentasi yang lebih tinggi daripada tahun 2018 (2017 $=31,7 \% ; 2018=0,2 \%$ ), sedangkan hasil tangkapan $>1.000 \mathrm{~kg}$ perkapal prosentasenya lebih rendah pada tahun 2017 dibandingkan tahun 2018 (2017 = 0,2\%; $2018=12 \%$ ) (Gambar 4). Hal tersebut menunjukkan bahwa hasil tangkapan ikan teri di TPI Morodemak tahun 2018 lebih tinggi daripada tahun 2017.

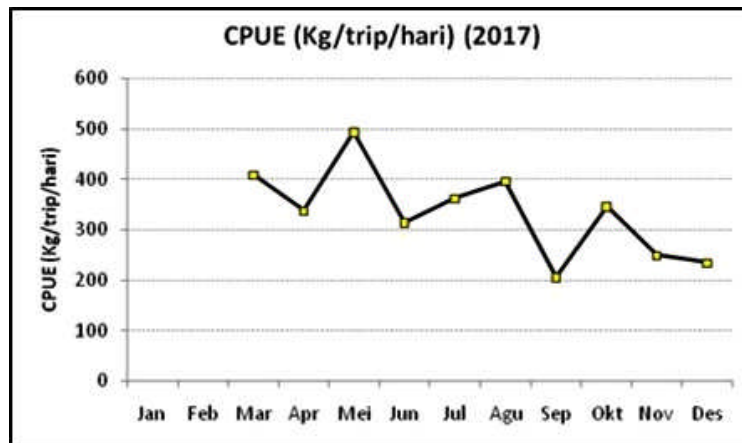

A

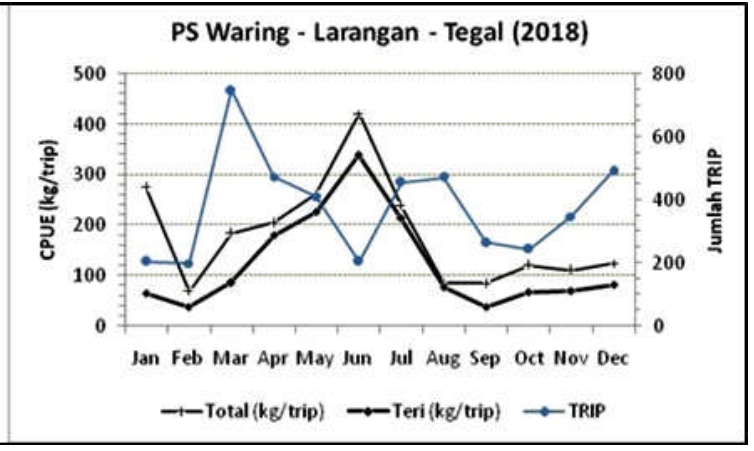

$B$

Gambar 3. Fluktuasi nilai CPUE ikan teri dari alat tangkap pukat cincin waring A) TPI Pulolampes, tahun 2017; B) TPI Larangan, tahun 2018.

Figure 3. CPUE fluctuation of anchovies caught by purse seine using waring in A) TPI Pulolampes, 2017; B) TPI Larangan, 2018.

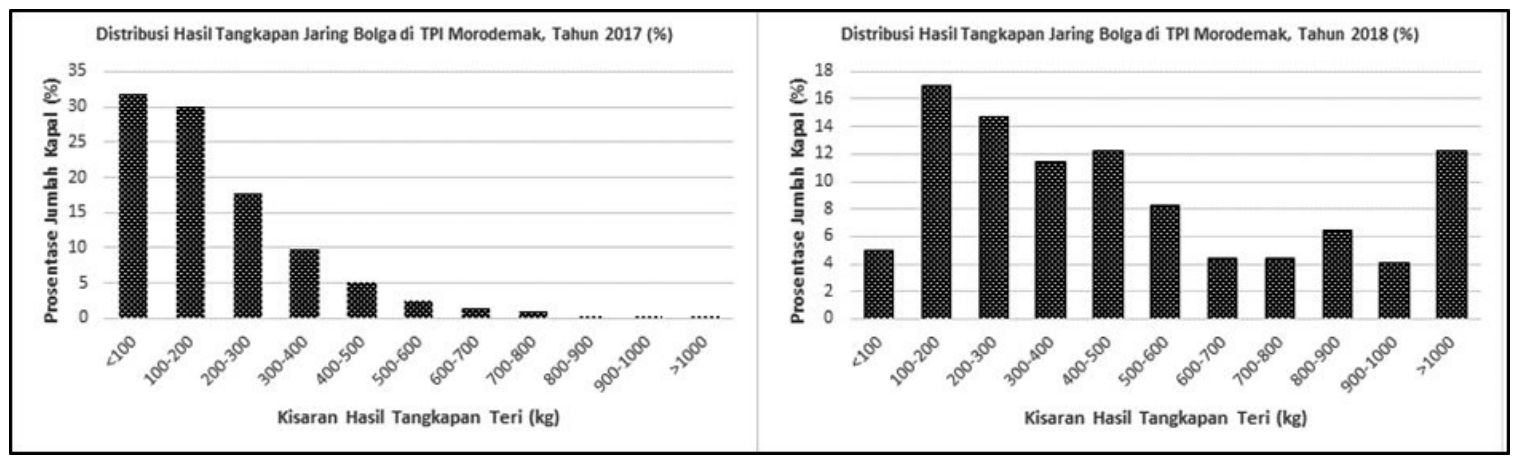

Gambar 4. Distribusi hasil tangkapan ikan teri di TPI Morodemak, tahun 2017 dan 2018.

Figure 4. Catch distribution of anchovies in TPI Mordemak, 2017 and 2018.

Dapat dilihat pada Gambar 5A bahwa variasi bulanan pendaratan ikan teri di Kabupaten Gresik tahun 2017 selama 6 bulan pertama hasil tangkapan menunjukkan lebih rendah dari 6 bulan kedua; hasil tangkapan terendah pada Januari-Februari sebanyak 0,2 ton dan 0,4 ton, sedang rata-rata tinggi terjadi pada Juli, Agustus, Septembar masing-masing berturut-turut 199 ton, 185 ton, dan 195 ton. Puncak musim penangkapan ikan teri di Pamekasan Madura, terjadi pada bulan Maret, Juni dan Oktober dengan nilai CPUE sekitar $30 \mathrm{~kg} /$ trip, dengan total nilai produksi lebih dari 300 ton. Bulan Agustus mempunyai hasil tangkapan yang terendah diantara bulan yang lain, yaitu sekitar 133,3 ton. Jumlah trip dari Januari hingga Desember 2018 cenderung mengalami peningkatan namun tertinggi terjadi pada Oktober, yaitu sebesar 13.999 trip (Gambar 5B).

Hasil tangkapan ikan teri tertinggi di TPI Pulolampes, Brebes terjadi pada bulan Juli, sedangkan fluktuasi kelimpahan ikan teri yang ditunjukkan besaran nilai CPUE (kg/trip/hari) menunjukkan puncak kelimpahan berlangsung sekitar Mei. Pola yang hampir sama juga dapat di ketahui di TPI Larangan, Tegal, dimana hasil tangkapan teri meningkat mulai bulan Maret dan puncak sekitar April-Juli, pada bulan bulan Agustus menurun kembali. Namun, puncak hasil tangkapan per unit upaya (CPUE kg/trip) sebagai indeks kelimpahan ikan teri terjadi sekitar Juni tercatat sebesar $338 \mathrm{~kg} /$ trip. Musim ikan teri di TPI Morodemak berdasarkan data 2017-2018 berlangsung antara bulan Mei sampai Juli. CPUE bulanan (rata-rata hasil tangkapan per trip) berkisar antara 126-542 kg/trip/hari (Gambar6).

\section{Parameter Biologi Ikan Teri Sebaran Ukuran Panjang}

Hasil pengukuran ikan teri seret putih (Stolephorus commersonnii) yang dilakukan di TPI Morodemak selama Februari hingga November 2019 berkisar anatara 4,75-9,0 cm MidLength (ML) dengan nilai modus 7,0 cm (Gambar 7). 


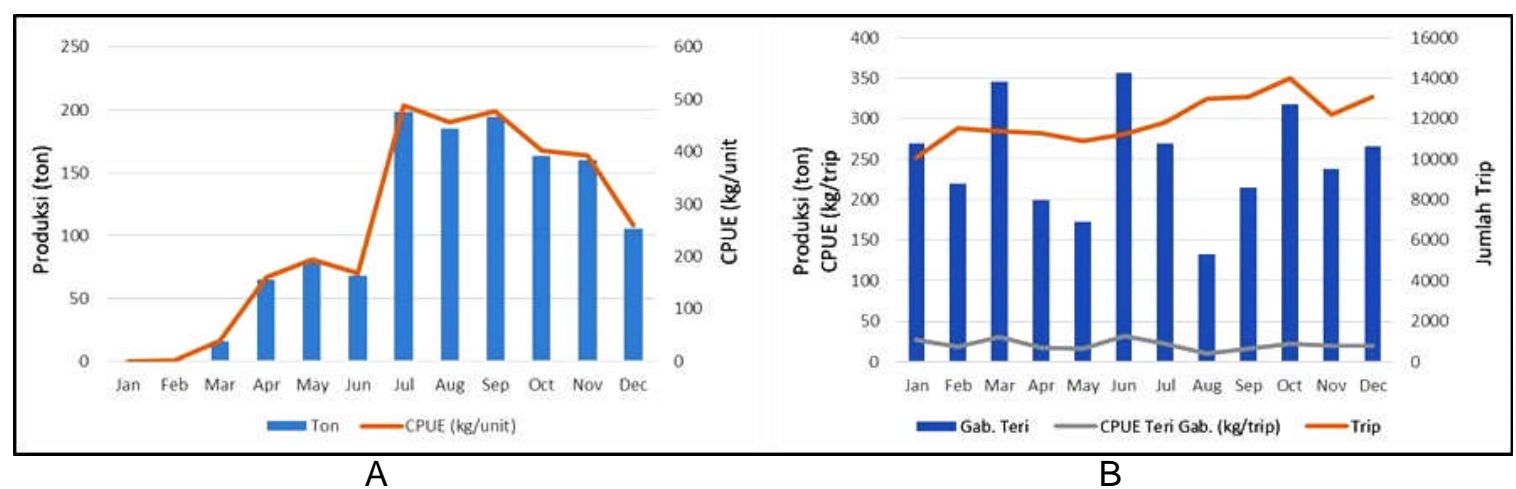

Gambar 5. Variasi bulanan hasil tangkapan ikan teri di Gresik tahun 2017 (A) dan variasi bulanan hasil tangkapan, jumlah trip dan CPUE ikan teri di Pamekasan tahun 2018 (B).

Figure 5. Monthly variation of anchovy catch in Gresik in $2017(A)$ and monthly variation of catches, number of trips and CPUE of anchovy in Pamekasan in 2018 (B).

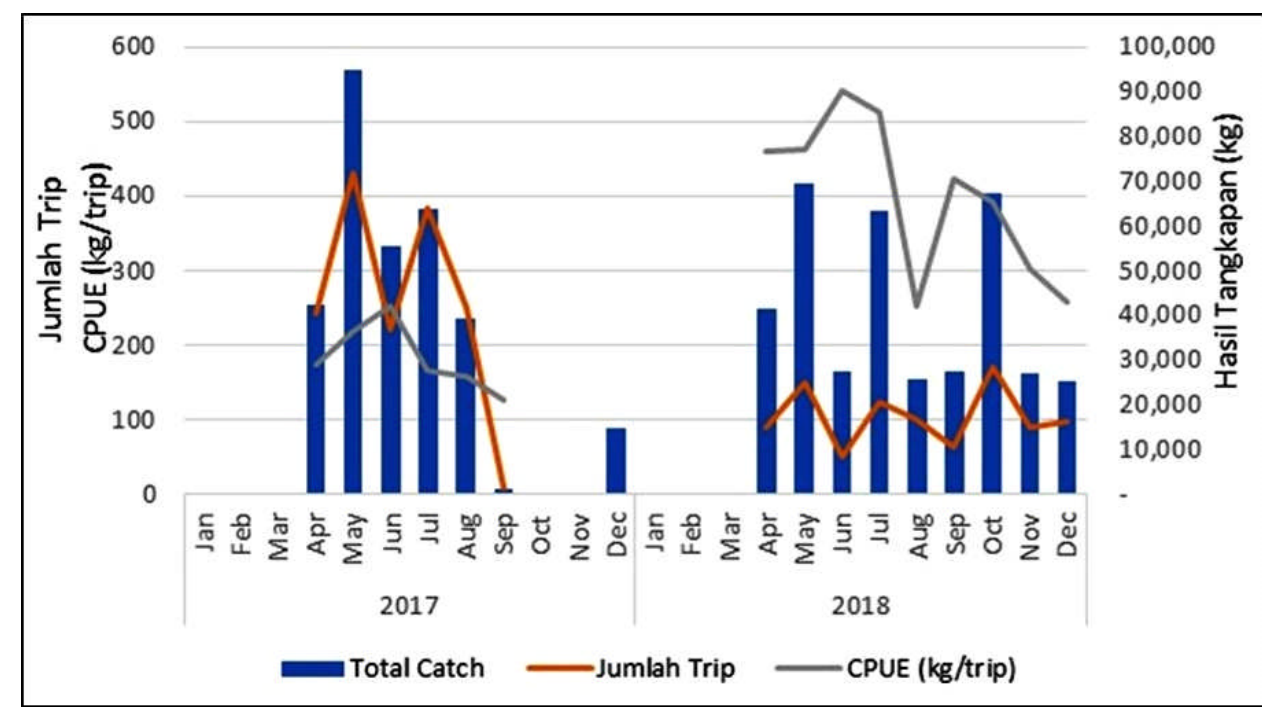

Gambar 6. Fluktuasi nilai CPUE ikan teri dari alat tangkap pukat cincin waring (jaring Bolga) di peraian Morodemak (Sumber: enumerasi 2017-2018).

Figure 6. Fluctuations of CPUE anchovy from Bolga nets in the Morodemak watershed (Source: enumeration 2017-2018).

\begin{tabular}{|c|c|c|c|c|c|c|c|c|c|c|}
\hline MidLength (cm) & Feb & Mar & Apr & May & Jun & Jul & Aug & Sep & Oct & Total \\
\hline 4,75 & - & - & - & - & - & - & - & - & 0.2 & 0.0 \\
\hline 5,00 & - & - & - & 0.2 & - & - & 0.6 & 0.8 & 0.5 & 0.3 \\
\hline 5,25 & - & 0.3 & - & - & - & 0.2 & 0.2 & 0.4 & 0.3 & 0.2 \\
\hline 5,50 & - & - & - & 0.3 & 1.3 & 0.7 & 3.0 & 6.6 & 0.7 & 1.6 \\
\hline 5,75 & - & 0.3 & - & 0.5 & 0.8 & 0.3 & 1.6 & 6.2 & 0.3 & 1.3 \\
\hline 6,00 & 3.0 & 0.7 & 2.7 & 3.5 & 5.8 & 5.8 & 15.2 & 13.4 & 2.7 & 6.4 \\
\hline 6,25 & 6.5 & 2.0 & 3.0 & 1.8 & 3.5 & 2.0 & 8.0 & 3.2 & 2.2 & 3.4 \\
\hline 6,50 & 23.5 & 10.7 & 10.3 & 15.5 & 13.5 & 14.8 & 40.4 & 8.8 & 14.5 & 18.0 \\
\hline 6,75 & 18.0 & 7.0 & 6.3 & 6.0 & 11.8 & 11.3 & 8.8 & 6.2 & 10.5 & 9.1 \\
\hline 7,00 & 29.0 & 17.0 & 27.3 & 22.3 & 30.8 & 337 & 11.6 & 142 & 29.0 & 23.8 \\
\hline 7,25 & 5.5 & 7.0 & 14.0 & 9.2 & 17.8 & 13.5 & 2.2 & 6.0 & 11.2 & 9.7 \\
\hline 7,50 & 9.0 & 31.0 & 26.7 & 21.8 & 13.3 & 14.3 & 5.0 & 18.8 & 20.2 & 17.5 \\
\hline 7,75 & 3.5 & 14.0 & 4.0 & 4.7 & 1.3 & 17 & 0.2 & 6.6 & 2.2 & 3.8 \\
\hline 8,00 & 1.5 & 9.3 & 5.0 & 10.0 & 0.5 & 15 & 2.0 & 8.4 & 4.3 & 4.9 \\
\hline 8,25 & 0.5 & 0.3 & - & 20 & - & 0.2 & 0.4 & 0.2 & 0.8 & 0.6 \\
\hline 8,50 & - & 0.3 & 0.7 & 17 & - & - & 0.6 & 0.2 & 0.5 & 0.5 \\
\hline 8,75 & - & - & - & 0.5 & - & - & - & - & - & 0.1 \\
\hline 9,00 & - & - & - & - & - & - & 0.2 & - & - & 0.0 \\
\hline
\end{tabular}

Gambar 7. Sebaran panjang bulanan ikan teri seret putih yang didaratkan di TPI Morodemak. Figure 7. Mothly length distribution of anchovy landed in Morodemak fishing port. 


\section{Hubungan Panjang-Berat}

Dari analisis hubungan panjang berat ikan teri seret putih menunjukkan pola pertumbuhan allometrik negatif dengan nilai $b<3$, dimana pertumbuhan panjang lebih cepat dibandingkan pertumbuhan beratnya seperti disampaikan pada Gambar 8 berikut.

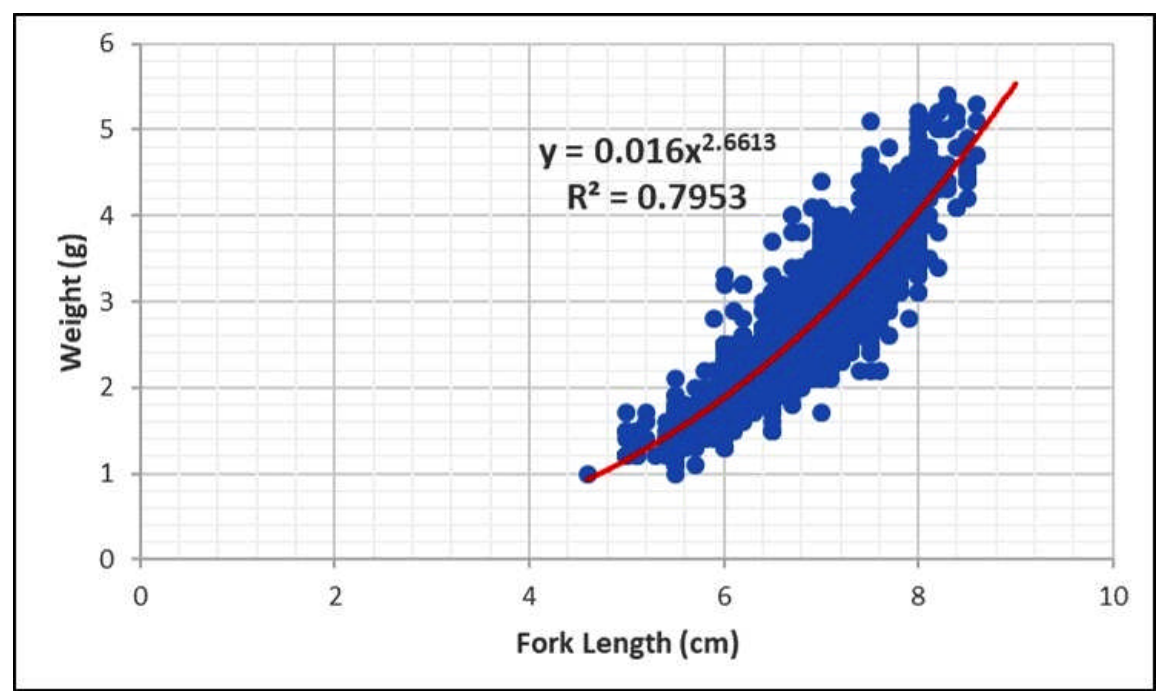

Gambar 8. Hubungan panjang-berat ikan teri yang didaratkan di TPI Morodemak.

Figure 8. Length weight relationship of anchovy landed in Morodemak fishing port.

\section{Panjang Rata-rata Tertangkap $\left(L_{c}\right)$}

Nilai Lc untuk ikan teri seret putih selama Februari hingga November 2019 adalah 6,89 cm. Ukuran ratarata tertangkap ikan teri pada penelitian ini hampir sama dengan modus kisaran ukuran yang didaratkan (Gambar 9).

\section{Parameter Pertumbuhan, Laju Kematian dan Tingkat Pemanfaatan}

Berdasarkan hasil analisis frekuensi panjang cagak ikan teri seret putih diperoleh panjang asimptotik $\left(\mathrm{L}_{\infty}\right)$ pada panjang cagak $9,5 \mathrm{~cm}$ dengan koefisien pertumbuhan $(K)=0,336$ per-tahun. Hasil analisis mortalitas total (Z) diperoleh nilai 1,92 per tahun. Dengan rata-rata suhu tahunan di perairan Laut Jawa $29^{\circ} \mathrm{C}$, maka jika dimasukkan dalam persamaan empiris Pauly (1980) didapatkan mortalitas alami (M) dari ikan teri seret putih adalah 0,84 per-tahun. Mortalitas penangkapan $(F)$ yang didapatkan dari $F=$ $Z$ - M adalah 1,08 per-tahun dengan rasio eksploitasi (E) yang diperoleh 0,56 pertahun. Grafik Von Bertalanffy Growth dan kurva hasil tangkapan ikan teri seret putih tersaji pada Gambar 10.

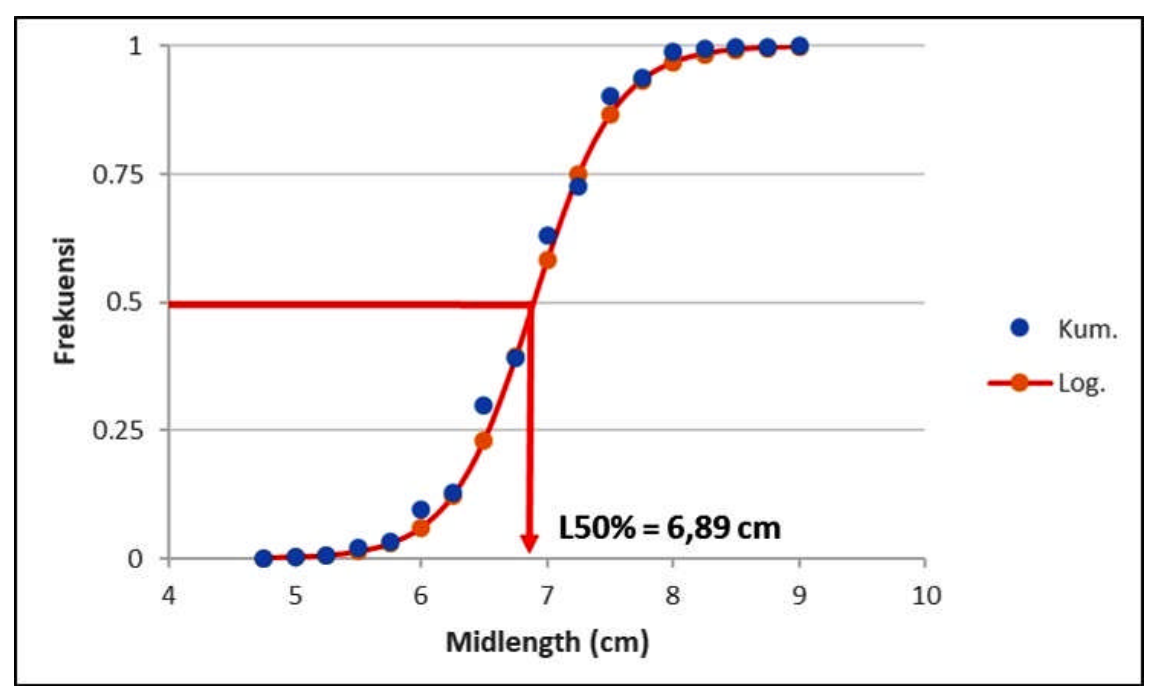

Gambar 9. Nilai panjang rata-rata tertangkap (L50) ikan teri seret putih didaratkan di TPI Morodemak.

Figure 9. Length of first capture of anchovy landed in Morodemak fishing port. 


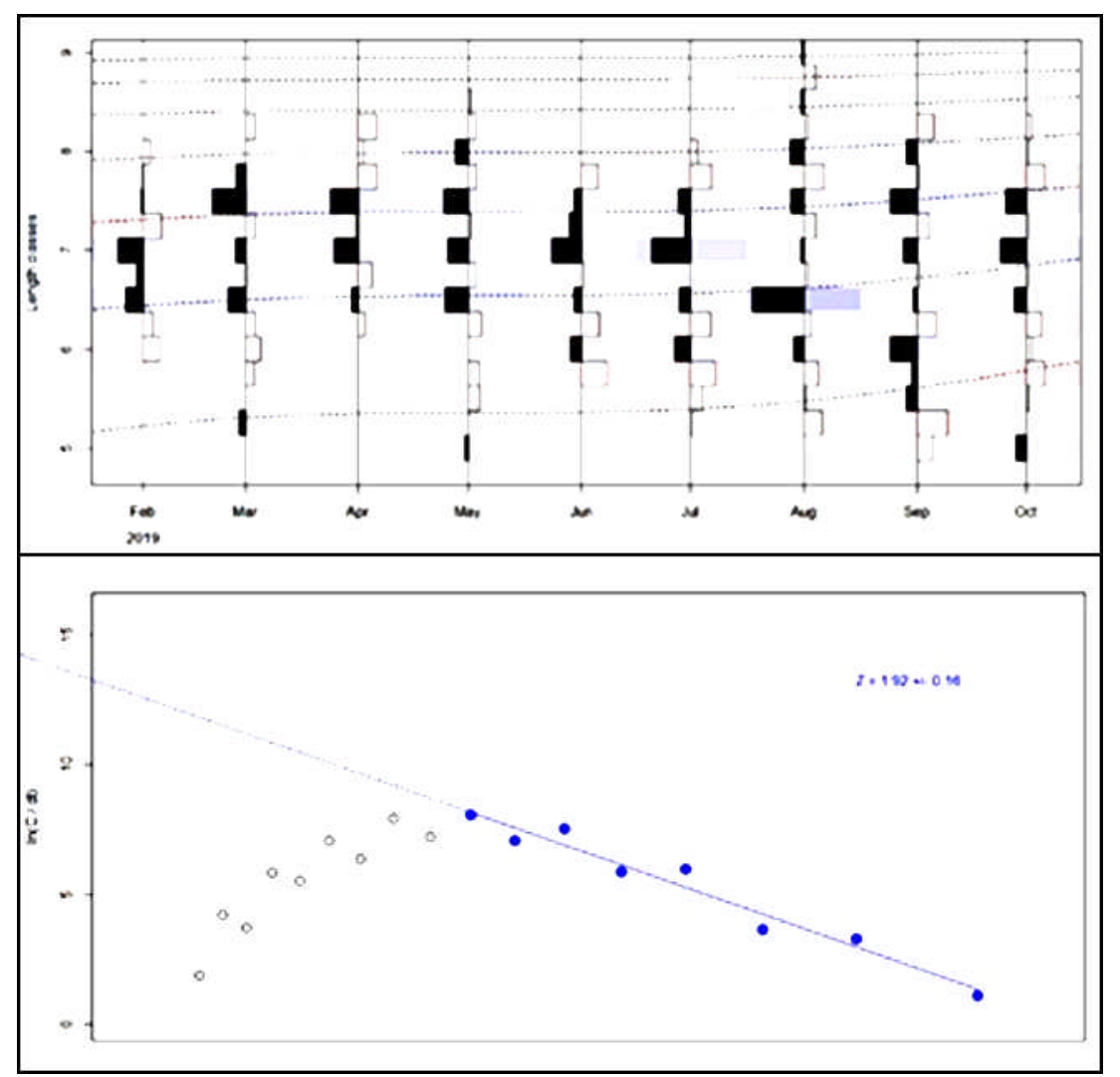

Gambar 10. Estimasi total mortalitas dengan metode catch curve menurut ukuran panjang ikan teri seret putih di Laut Jawa.

Figure 10. Total mortality estimation with catch curve method by length of anchovy in the Java Sea.

\section{Bahasan}

Sumberdaya teri tersebar luas di pantai utara Jawa-Madura dan dapat ditemukan hampir di setiap kabupaten/kota sebagai usaha perikanan skala kecil dengan kapal penangkap berukuran $<20 \mathrm{GT}$. Dua jenis alat penangkapan ikan (API) dengan target species teri adalah pukat cincin waring dan payang, sedang pengoperasian bagan semakin berkurang. Perikanan skala kecil umumnya melakukan aktivitas penangkapan secara harian (one day fishing); daerah penangkapan di perairan pantai yang dangkal dan dekat dengan basis perikanan. Jaring yang dipakai umumnya menggunakan waring dengan mata jaring ( mesh size) kecil $(3 / 8$ inchi $=10 \mathrm{~mm})$. Penggunaan waring tersebut tentu berkaitan dengan ukuran ikan target yang kecil. Hasil pengukuran panjang ikan di Morodemak memperlihatkan sebaran ukuran panjang cagak (fork-length) ikan teri berkisar antara 4,75-9,0 $\mathrm{cm}$ dan bersifat polymodal dengan ukuran rata-rata $\left(L_{c}\right)$ sebesar $6,42 \mathrm{~cm}$. Tiga jenis teri sering ditemukan sebagai hasil tangkapan yang diperoleh nelayan Di sepanjang pantai utara Jawa dan Selat Madura yaitu teri garis putih, teri garis hitam dan teri nasi. Teri nasi mudah dibedakan dengan jenis teri lainnya karena berukuran lebih kecil dan berwarna putih transparan kepala lebih pendek, selempang lateral relatif lebih kecil (Hutomo et al., 1970).

Musim ikan teri di perairan pantura bagian barat (Pulolampes, Larangan, Morodemak) diperkirakan berlangsung sekitar musim timur/tenggara (Mei sampai Juli), pola-pola musiman hasil tangkapan mempertegas hal tersebut; sedang di perairan pantura bagian timur musim teri diduga berlangsung pada awal musim timur dan berjalan cukup lama hingga November (musim peralihan 2); namun di Pamekasan musim tangkapan teri tidak menunjukkan pola yang jelas. Variasi musiman teri menurut daerah penangkapan diduga menggambarkan pola pergerakan (migrasi) ikan itu sendiri di sepanjang pantai utara Jawa. Perairan bagian timur mangalami puncak musim ikan teri lebih cepat dibandingkan dengan perairan bagian barat, hal ini diduga karena datangnya musim timur tejadi lebih cepat di perairan bagian timur. Pada musim timur, massa air laut bergerak dari Timur (laut Flores dan Selat Makasar) ke barat memasuki laut Jawa mendorong massa air salinitas rendah di Laut Jawa kembali ke barat sampai ke laut Cina Selatan melewati Selat Karimata (Najid et al., 2012). Massa air laut yang bergerak dari timur tersebut mempunyai salinitas yang tinggi, hal ini menyebabkan pada 
musim timur nilai salinitas cenderung lebih tinggi daripada musim barat. Adanya peningkatan nilai salinitas tersebut diduga merupakan kondisi yang cukup disukai oleh ikan teri, sehingga hasil tangkapan melimpah. Berdasarkan indeks musim penangkapan (IMP) Rahmawati et al. (2013) menduga di daerah Pemalang, ikan teri tertangkap sepanjang tahun, puncak musim penangkapan teri berlangsung dua kali yaitu sekitar Maret dan Juli-September. Di daerah Tuban puncak musim penangkapan teri berlangsung antara Oktober hingga Januari, musim paceklik terjadi pada April-Juli (Gunawan, 2004).

Potensi produksi teri bervariasi di masing-masing daerah pendaratan ikan. Total ikan teri yang didaratkan umumnya bergantung pada jumlah kapal penangkap dan kelimpahan stok. Hasil tangkapan per unit upaya (CPUE, indeks kelimpahan relatif) diduga makin ke arah timur semakin rendah tapi dengan musim lebih panjang. CPUE yang cenderung lebih tinggi umumnya diperoleh dari pukat cicnin yang sifatnya lebih efektif dalam penangkapan. Ini terlihat di Pulolampes, Larangan dan Morodemak, di daerah lain umumnya berupa alat payang. Armada penangkap payang umumnya mempunyai ukuran yang relatif lebih kecil dibandingkan dengan pukat cincin waring, disamping itu teknologi alat bantu dalam menangkap ikan pada pukat cincin waring lebih lengkap, sehingga hal ini menyebabkan pukat cincin waring lebih efektif daripada payang. Basis perikanan teri di daerah Pemalang (Jawa Tengah), diupayakan dengan payang gemplo/payang jabur, diperkirakan berperan penting dalam produksi serta kemungkinan pola pergerakan lokal dari sumberdaya teri di pantura Jawa. Menurut Rahmawati (2013) teri menjadi salah satu target penangkapan pada alat payang jabur (sekitar 24\%). Pada jaring arad/pukat dasar di Cirebon dan Pemalang hasil tangkapan teri kira-kira $7,5 \%$ dari total ikan pelagis (BPPL, 2015).

Hasil pengukuran ikan teri selama Februari hingga November 2019 menunjukkan bahwa tidak ditemukan ikan teri dalam kondisi juvenil atau berukuran kecil (< $2 \mathrm{~cm}$ ). Fauziyah et al. (2016) menyebutkan bahwa ikan teri ukuran kecil (juvenile) belum siap bergabung ke dalam populasi teri dewasa. Lebih lanjut Dewanti et al. (2014) menyatakan bahwa populasi ikan dewasa merupakanikan yang suka hidup bergerombol dan bergerak cepat secara bersamaan dan beriringan. Akan tetapi populasi ikan muda berkemungkinan masih berada di sekitar habitat pemijahan, karena belum mampu bergerak cepat mengikuti populasi ikan dewasa.

Pola pertumbuhan alometrik negatif hasil penelitian ini diduga ikan yang belum matang gonad banyak ditemukan pada lokasi sampling. Ikan teri yang matang gonad cenderung mempunyai bobot yang lebih besar dibandingkan dengan yang belum matang gonad, sehingga ikan teri yang matang gonad cenderung tidak alometrk negatif. Dominannya ikan yang belum matang gonad tersebut menunjukkan bahwa daerah penangkapan ikan teri di Laut Jawa merupakan daerah asuhan dan daerah mencari makan. Menurut Türkmen et al. (2002), faktor-faktor yang mempengaruhi pola pertumbuhan ikan adalah perbedaan jumlah dan variasi ukuran ikan yang diamati, tahap perkembangan ikan, jenis kelamin dan faktor lingkungan serta perkembangan ontogenetiknya. Ricker (1975) juga menyatakan bahwa faktor ekologis dan biologis sangat mempengaruhi pola pertumbuhan ikan. Keadaan lingkungan yang sering berubah atau kondisi dari ikannya juga berubah maka hubungan panjang - berat akan sedikit menyimpang dari $b=3$ (Merta, 1993). Effendie (2002) mengatakan bahwa nilai b berhubungan dengan kondisi ikan, sedangkan kondisi ikan bergantung pada makanan, umur, jenis kelamin dan kematangan gonad.

Analisis ukuran pertama kali tertangkap (LC) menunjukkan hasil yang tidak berbeda dengan modus dari kisaran ukuran yang tertangkap, yaitu $6,89 \mathrm{~cm}$. Nilai Lc yang diperoleh dari penelitian ini cenderung lebih besar dari nilai yang diperoleh Dewanti et al. (2014) di perairan sekitar Pemalang dengan alat tangkap payang yaitu $5,7 \mathrm{~cm}$ dan penelitian yang dilakukan oleh Fauziyah et al. (2016) di perairan Muara Sungsang, Sumatera Selatan dengan alat tangkap bagan tancap, yaitu sekitar $6,1 \mathrm{~cm}$ (Juli) dan $6,7 \mathrm{~cm}$ (September). Diduga karena alat tangkap yang digunakan dan lokasi penangkapan yang berbeda dapat menyebabkan perbedaan nilai panjang pertama kali tertangkap (LC). Terdapat tiga faktor yang menyebabkan terjadinya perbedaan nilai Lc. Faktor yang pertama adalah perbedaan ukuran mata jaring yang digunakan saat menangkap, yang kedua adalah waktu menangkap ikan (bulan atau musim) dan yang ketiga adalah daerah penangkapan (fishing ground) (Hargiyatno et al., (2013). Menurut Erzini (1990), penggunaan data berbasis panjang ikan mempunyai beberapa keterbatasan, diantaranya adalah ukuran sampel dan lebar interval, sehingga hal ini dapat menyebabkan perbedaan nilai LC.

Analisis parameter pertumbuhan pada penelitian ini menunjukkan hasil yang berbeda dengan penelitian yang dilakukan oleh Rauf et al. (2019) di perairan sekitar Ternate, Maluku Utara yang dieksploitasi dengan alat tangkap bagan perahu $\left(\mathrm{L}_{\infty}=7,19 \mathrm{~cm} ; \mathrm{K}\right.$ $\left.=0,26 ; \mathrm{t}_{0}=-0,99\right)$. Perbedaan nilai dalam parameter pertumbuhan dapat disebabkan oleh beberapa hal, 
menurut Moazzam et al. (2005) diantaranya adalah periode pengambilan sampel, ukuran sampel ikan dan daerah penangkapan, Amin et al. (2015) menambahkan penyebab lainnya adalah usia dan jenis kelamin ikan. Perbedaan dalam parameter lingkungan, ketersediaan makanan, predasi, eksploitasi dan jenis alat tangkap yang digunakan, mempengaruhi parameter pertumbuhan (Ghosh et al., 2016). Lebih lanjut Suwarso \& Wujdi (2015) menyatakan bahwa perbedaan panjang maksimum dapat dipengaruhi oleh perbedaan kondisi habitat dan tekanan dari kegiatan penangkapan ikan di setiap perairan, habitat dengan kandungan gizi atau ketersediaan makanan alami yang cukup dapat mendukung pertumbuhan ikan yang optimal, sementara kegiatan penangkapan ikan intensif tidak memberikan peluang ikan untuk tumbuh lebih besar sehingga panjang maksimum menjadi lebih kecil.

Nilai mortalitas akibat penangkapan dalam penelitian ini ( 1,08 per-tahun) lebih tinggi daripada nilai kematian alaminya $(0,84$ per-tahun), hal ini mengindikasikan bahwa ikan teri dalam penelitian ini telah mangalami tekanan penangkapan yang tinggi. Menurut Sparre \& Venema (1998), tingginya nilai mortalitas akibat penangkapan ikan dan rendahnya nilai mortalits alami dapat mengindikasikan terjadinya kondisi penangkapan ikan yang berlebih. Oleh karena itu perlu dilakukan usaha untuk mencapai kondisi optimal, yaitu nilai mortalitas akibat penangkapan yang seimbang dengan nilai mortalitas alami, misalnya dengan melakukan pengurangan terhaap tekanan penangkapan. Nilai $E$, atau tingkat eksploitasi didapatkan dari perbandingan antara nilai mortalitas akibat penangkapan $(F)$ dengan nilai mortalitas total $(Z)$, yaitu sebesar 0,56 , yang mempunyai arti bahwa $56 \%$ mortalitas ikan merupakan hasil dari kegiatan penangkapan ikan selama penelitian ini. Gulland (1983) mengemukakan bahwa ketika mortalitas alami dan mortalitas akibat penangkapan mempunyai nilai yang seimbang (yaitu, tingkat eksploitasi $(E)=0,5)$, maka stok dalam keadaan sehat dan mengalami eksploitasi secara optimal. Tingkat eksploitasi dalam penelitian ini $(E=$ $0,56)$ memiliki nilai yang lebih tinggi dari nilai eksploitasi optimal 0,5 per-tahun, sehingga perlu perhatian yang serius dalam pengelolaannya, misalnya dengan pembatasan jumlah armada penangkapan.

Dengan mengoperasikan alat pukat cincin waring tersebut seringkali timbul konflik di lapangan karena spesifikasi jaring tidak sesuai dengan yang termaktub dalam PERMEN KP No. 71 Tahun 2016 akibat penggunaan waring mempunyai ukuran mata $3 / 8$ inchi (Mahiswara \& Suwarso, 2017). Dengan target spesies ikan teri tentu penggunaan ukuran mata jaring 1 inchi yang sesuai aturan pasti tidak akan memperoleh hasil tangkapan, tapi di lapangan petugas pemerintah nampaknya tidak memahami hal tersebut.

\section{KESIMPULAN}

Dua jenis alat penangkapan ikan utama dengan target utama ikan teri di perairan utara Jawa adalah pukat cincin waring dan payang dengan usaha perikanan bersifat skala kecil, melakukan trip harian, dan dengan armada penangkap berukuran dibawah 20 GT. Jaring yang dipakai umumnya menggunakan waring dengan mata jaring kecil ( $3 / 8$ inchi). Jumlah upaya penangkapan diperkirakan semakin bertambah. Daerah penangkapan di perairan pantai yang dangkal, dekat dengan basis perikanan. Musim ikan teri di pantura bagian barat (Pulolampes, Larangan, Morodemak) diperkirakan berlangsung pada saat musim timur/tenggara (Mei sampai Juli), sedangkan di pantura bagian timur musim teri diduga berlangsung pada awal musim timur dan berlangsung cukup lama hingga November (musim peralihan 2). Pola petumbuhan ikan teri penelitian ini bersifat alometrik negatif. Nilai panjang pertama kali tertangkap (LC) adalah sekitar $6,89 \mathrm{~cm}$. Panjang asimptotik $\left(\mathrm{L}_{\infty}\right)$ adalah sekitar $9,5 \mathrm{~cm}$ (panjang cagak), dengan koefisien pertumbuhan (K) adalah 0,336 per-tahun. Nilai mortalitas total $(Z)$ adalah 1,92 per-tahun, mortalitas alami (M) adalah 0,84 per-tahun dan mortalitas penangkapan $(F)$ adalah 1,08 per-tahun. Tingkat pemanfaatan lebih dari $0,5(E=0,56)$, sehingga perlu hati-hati dalam eksploitasinya, misalnya dengan pembatasan jumlah kapal penangkap yang beroperasi.

\section{PERSANTUNAN}

Makalah ini merupakan hasil penelitian dari kegiatan "Penelitian Karakteristik Biologi Perikanan, Habitat Sumber Daya dan Potensi Produksi Sumber Daya Ikan di WPP 712 Laut Jawa" yang didanai oleh APBN Tahun Anggaran 2017-2019 melalui Program Riset dan SDM Kelautan dan Perikanan di Balai Riset Perikanan Laut. Kontributor utama dari karya tulis ilmiah ini adalah penulis pertama adalah Achmad Zamroni.

\section{DAFTAR PUSTAKA}

Amin, A. M., Sabrah, M. M., El-Ganainy, A., \& ElSayed, A. Y. (2015). Population structure of Indian mackerel, Rastrelliger kanagurta (Cuvier, 1816), from the Suez Bay, Gulf of Suez, Egypt. Int. J. Fish. Aquat. Stud., 3(1), 68-74. DOI: http:/ /dx.doi.org/10.22271/fish 
Dewanti, R. O. N., Ghofar, A., \& Saputra, S. W. (2014). Beberapa Aspek Biologi Ikan Teri (Stolephorus devisi) yang Tertangkap Payang di Perairan Kabupaten Pemalang. Diponegoro Jounal of Maquares, 3(4), 102-111. URI: https:// ejournal3.undip.ac.id/index.php/maquares/article/ view/6661/6426

Effendie, I. M. (2002). Biologi perikanan (p. 163). Bogor: Yayasan Pustaka Nusantara.

Erzini, K. (1990). Sample size and grouping of data for length-frequency analysis. Fish. Res., 9, 355366. DOI: https://doi.org/10.1016/01657836(90)90053-X

Fauziyah, F., Hadi, H., Saleh, K., \& Supriyadi, F. (2016). Distribusi Ukuran Ikan Teri (Stolephorus sp) yang Ditangkap pada Perikanan Bagan Tancap di Muara Sungsang Sumatera Selatan. Marine Fisheries, 7(2), 161-169. URI: https:// journal.jpb.ac.id/index.php/jpsp/article/view/15747/ 11609

Ghosh S, Rao, M. V. H., Mahesh, V. U., Kumar, M. S., \& Rohit, P. (2016). Fishery, Reproductive Biology and Stock Status of the Indian Mackerel Rastrelliger kanagurta (Cuvier, 1817), Landed Along the North-east Coast of India. Indian Journal Fish. 63(2), 33-41. DOI: 10.21077/ijf.2016.63.2.53399-05

Gulland, J. A. (1983). Fish Stock Assement: A Manual of Basic Method. John Wiley and Sons. Inc, NewYork.

Gunawan, A. (2004). Analisis Pola Musim Penangkapan dan Tingkat Pemanfaatan Ikan Teri Di Kabupaten Tuban, Jawa Timur. Skripsi. Departemen Pemanfaatan Sumberdaya Perikanan, Fakultas Perikanan Dan Ilmu Kelautan, Institut Pertanian Bogor. $105 \mathrm{Hal}$.

Hargiyatno, I. T., Sumiono, B., \& Suharyanto, S. (2013). Catch rate, stock density and some biological aspect of white prawn (Penaeus merguensis) in Dolak wat rs, Arafura Seas. Bawal, 5(2), 123-129. DOI: http://dx.doi.org/10.15578/ bawal.5.2.2013.123-129

Merta, I. G. S. (1993). Hubungan panjang - berat dan factor kondisi ikan lemuru, Sardinella lemuru Bleeker, 1853 dari perairan Selat Bali. Jur. Pen. Per. Laut. 73, 35 - 44.

Moazzam, M., Osmany, H. B., \& Zohra, K. (2005). Indian mackerel (Rastrelliger kanagurta) from $\mathrm{Pa}$ - kistan. Some aspects of biology and fisheries. Rec. Zool. Surv. Pakistan, 16, 58-75.

Pauly, D. (1980). On the interrelationships between natural mortality, growth parameters and mean environmental temperature in 175 fish stocks. Journal of Conservation and Exploring Meridien, 39, 175192. DOI: https://doi.org/10.1093/icesjms/39.2.175

Pauly, D. (1984). Fish population dynamics in Tropical Waters: A Manual for Use With Programable Calculators (p. 325). Manila: ICLARM

Rahmawati, M., Fitri, A. D. P., Wijayanto, D. (2013). Analisis Hasil Tangkapan Per Upaya Penangkapan Dan Pola Musim Penangkapan Ikan Teri (Stolephorus Spp.) Di Perairan Pemalang. Journal Of Fisheries Resources Utilization Management And Technology, 2(3), 213-222. https:// ejournal3.undip.ac.id/index.php/jfrumt/article/view/ $3851 / 3754$

Rauf, F. H., Tangke, U., \& Namsa, D. (2019). Dinamika Populasi Ikan Teri (Stolephorus sp) yang di Daratkan di Pasar Higienis Kota Ternate. Jurnal Biosainstek, 1(1), 1-9. URI: http:// www.jurnal.ummu.ac.id/index.php/BIOSAINSTEK/ article/view/206/126

Ricker, W. E. (1975). Computation and interpretation of biological statistics of fish populations. Fish. Res. Bd. Can. Bull. 191, 382. URI: https://www.dfompo.gc.ca/Library/1485.pdf

Sokal, R.R., \& Rohlf, F.J. (1987). Introduction to biostatistics, 2nd edn (pp. 160-184). New York: Freeman Publication.

Sparre, P., \& Venema, S. C. (1998). Introduction to tropical fish stock assessment. Part 1: manual. FAO Fish. Tech. Paper. No. 306.1, Rev. 2 (p. 407). Rome: FAO.

Suwarso, S., \& Wujdi, A. (2015). Dinamika Populasi dan Estimasi Rasio Potensi Pemijahan Ikan Lemuru (Sardinella lemuru Bleeker, 1853) di Teluk Prigi, Jawa Timur. J. Lit. Perikan. Ind., 21(3), 177186. DOI: http://dx.doi.org/10.15578/ jppi.21.3.2015.177-186

Türkmen, M., Erdogan, O., Yildirim, A., \& Akhyurt, I. (2002). Reproductive tactics, age and growth of Capoeta capoeta umla Heckel 1843 from the Askale Region of theKarasu River, Turkey. Journal Of Fsheries Research. 54, 317-328. DOI: https://doi.org/10.1016/S0165-7836(01)00266-1 